\title{
透析患者に多発する後天性腎囊胞の発生メカニズム 一実験的研究一
}

\author{
小野 慶治王幸 則* \\ 小野外科クリニック 福岡赤十字病院腎センター* \\ (平成 1 年 6 月 9 日受付, 同 2 年 2 月 20 日受理)
}

key words : 後天性腎囊胞, 蓚酸, 尿細管拡張, ビタミンC

〈要旨〉

長期透析患者に多発する後天性腎囊胞の発生メカニズムは解明されていないが, 臨床上の観察から葆酸カルシウム (OxCa) の尿細管内沈着によって尿細管内圧を上昇させ囊胞が形成されるのではないかと疑い, $5 / 6$ 腎摘および正常 ラットで実験的に検討した。

まず, 蓚酸 $(O x)$ の前駆物質であるビタミンC (VC) を大量に与えた $5 / 6$ 腎摘ラットでは投与開始 11 か月後にしか OxCa の尿細管内沈着は認められず，すでにこの時点では $5 / 6$ 腎摘による急激な腎実質の減少に起因する renotropic growth factor の放出によって, VC 投与の有無にかかわりなく尿細管の拡張が認められ OxCa の沈着と後天性腎囊胞 形成との関連性は証明出来なかった。

そこで，5/6 腎摘ラットに直接蓚酸ナトリウム $(\mathrm{OxNa})$ を与えると，非投与の $5 / 6$ 腎摘ラットよりも早期にしかも 強い尿細管の拡張がみられた。

さらに正常ラットに OxNa を投与すると7日目には OxCa が尿細管内に沈着し，腎機能低下はないのに尿細管の拡 張が起こり, これらの变化は経時的に強くなっていった。

以上の結果から，末期腎不全患者に好発する後天性腎囊胞の発生メカニズムの一つとして OxCa の尿細管内沈着が 関与していることが実験的に証明されたと考えられる。

\section{Pathogenesis of acquired renal cyst formation in hemodialysis patients -Experimental study-}

Keiji Ono, M. D., Yukinori Oh, M. D.*

Ono Geka Clinic ; Fukuoka Red Cross Hospital*

The present study was undertaken to determine whether the oxalate deposits seen in renal tubules are a causative factor in the development of acquired renal cysts in chronic renal failure. Thirty $5 / 6$ nephrectomized rats had free access to water containing $8 \mathrm{mg} / \mathrm{m} l$ of vitamin $C$ (oxalate precursor) and $20.5 / 6$ nephrectomized rats were given tap water without vitamin $\mathrm{C}$. Oxalate deposits were found on microscopy in the renal tubules of the vitamin C-treated rats in the 11 th and 12 th postnephrectomy months; however, acquired renal cysts were noted far in advance of the appearance of oxalate crystals. It has been suggested that the tubular dilatation seen in 5/ 6 nephrectomized rats is caused by an abrupt decrease in the functioning renal mass, leading to the production of a so-called "renotropic growth factor." However, oxalate deposits and renal tubular dilatation in oxalate-treated $5 / 6$ nephrectomized rats preceded the renal tubular dilatation of untreated partially nephrectomized rats. In addition, these histological changes in the kidney were also seen in healthy rats which were given oxalate orally and subcutaneously.

The present study suggested that the pathogenesis of acquired renal cysts is multifactorial. Renotropic factor may play an important role in nephron hyperplasia, but oxalate deposits in the renal tubules seem to be an

小野 慶治 小野外样クリニック important factor in the formation of these cysts.

干 812 福岡市博多区博多駅東 2-17-5（092-472-5851） 


\section{緒言}

近年, 透析技術の進歩や腎移植の成績向上によって末 期腎不全患者は長期に生存し, しかも生産性の高い人生 を楽しめるようになった。こ机は末期賏不全症の病態生 理やそれに対する処置が多方面から研究された成果であ るが，しかし，これら患者自身の病腎に対する関心は極 めて薄いといえる。

これらの病腎ではほとんど排泄機能が消失していると はいえ, 種々な形態学的な変化を起こす。例えば, 透析

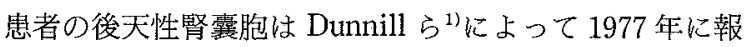
告されて以来, 約 $50 \%$ 症例で認められて, 出血や疼痛 を伴い珍しい合併症ではなく腎の悪性腫瘍の発生と深い 関係があるのではないかと疑われている.しかし，その 発生メカニズムについてはいくつかの仮説が発表されて はいるが，まだはっきりと解明されてはいない2). $\mathrm{OxCa}$ の沈着や $\beta_{2}-\mathrm{MG}$ 由来の結状物によって尿細管が狭窄な いしは閉塞して尿細管が囊胞状に拡張するという考え方 が臨床所見から示唆されている ${ }^{3 \sim 6)}$. 最近, 我久は透析患 者で血中 Ox 值と腎のサイズとの間に強い正の相関性が あることを見出しで7, 後天性腎囊胞発生のメカニズム に関心を持った，そこで，OxCa の尿細管内沈着によっ て後天性腎囊胞が発生するのではないかと疑い，5/6 腎 摘および正常ラットを使い実験的に検討した。

\section{方法}

この研究は 3 つの実験から構成されている。

実験 I：体重約 $220 \mathrm{~g}$ の Wistar 系ラット 50 匹で 5/6 腎摘を行い腎不全状態を作った。つまり，ペントバルビ タール腹腔内麻酔下に左腎の上・下両極 $1 / 3$ を電気焼灼 し，さらに 1 週間後に右側腎門部で動静脈を結禁して腎 実質を $1 / 6$ に減少させた。これらの腎不全ラットを蛋白 量 $26 \%$ の飼料で最長 12 か月間飼育し， 30 匹には Ox の 前駆物質である $\mathrm{VC}^{8)} 8 \mathrm{mg} / \mathrm{m} l$ を含む水を自由に与え, 残り 20 匹にはVCを与えずコントロール群とした。血 清クレアチニン $(\mathrm{Cr}), \mathrm{Ht}$, 体重を毎月測定しクレアチニ ンクリアランス $(\mathrm{CCr})$ を $1,3,6 ， 8,11$ か月目に 調べた．また，血漿および尿中 $\mathrm{Ox}$ と血漿 VC 值を 3 ， 8 加目に測定した。 ラットは定期的に，あるいは生存 が危ぶまれるほど弱った場合に全麻下に腹部大動脈から 脱血し犠牲死させた。

実験 II : $5 / 6$ 㻉摘ラット 10 匹を 2 群に分けA群には $5 / 6$ 腎摘 7 日目から葆酸ナトリウム $(\mathrm{OxNa}) 2 \mathrm{mg} / \mathrm{m} l$ を含むサッカリンで甘くした水を自由に飲ませ，さらに $\mathrm{OxNa} 5 \mathrm{mg}$ を毎日皮下に注射した。一方，B群では OxNa を与えずに対照とした. $5 / 6$ 腎摘 12 日後から両群 のラットを毎週 1 匹ずつ Cr と CCr 測定後に犠牲死させ た.

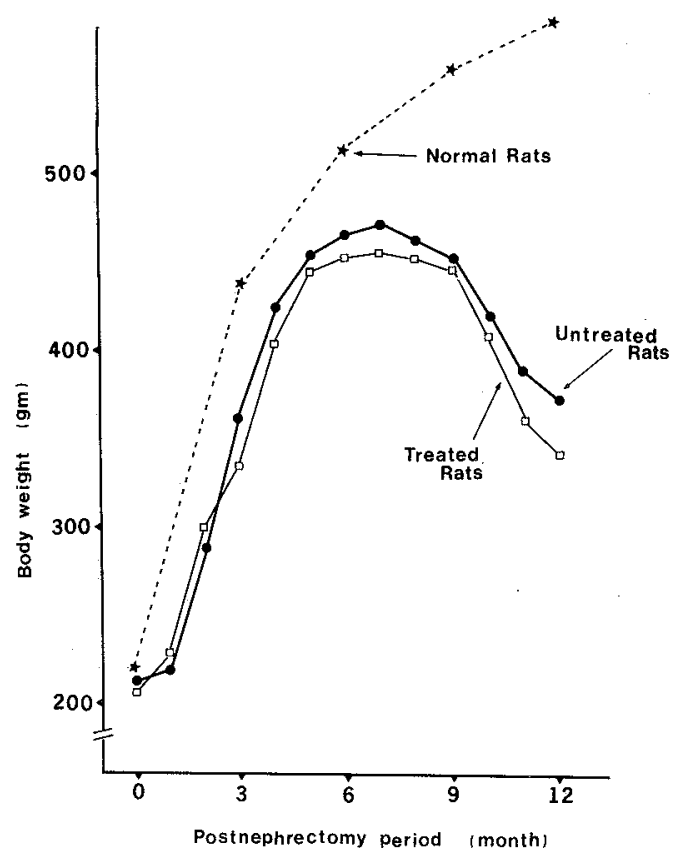

図 1 Body weight of $5 / 6$ nephrectomised rats treated and untreated with vitamin $\mathrm{C}$.

実験III：正常ラット 6 匹に OxNa $2 \mathrm{mg} / \mathrm{ml}$ を含み人 工甘味された水を与え，さらに $\mathrm{OxNa} 10 \mathrm{mg}$ を毎日皮 下に注射した。OxNa 投与開始 7 日目から毎週 1 匹ずつ 腹腔内麻酔下に殺した。ラットは犠牲死時に腎を摘出し HE, PAS 染色標本で組織学的検查を行い, 腎囊胞形成の 程度を 0 \#称した ${ }^{17)}$. この実験ではラットの心, 肝, 脾, 甲状腺の組織標本も検鏡した。

血液は採取後 15 分以内に血漿を分離し $-20^{\circ} \mathrm{C}$ に凍結 した。 Ox は脱蛋白後 Dionex HPIC-AS4A 分離カラム を使い capillary gas chromatography 法"9)によって測定 （凍結血漿を空輸し，米国 Galbraith Lab. Inc.にて）し

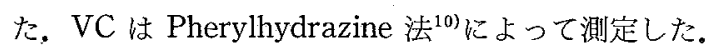

\section{結果}

実験 I ：手術死したラットはなく全て 1 か月以上生存 した. VC 投与・非投与 $5 / 6$ 腎摘ラットの経時的な体重, $\mathrm{Cr}, \mathrm{CCr}$ の変化は図 1，2，3亿まとめられている，5/ 6 腎摘後 1 か月間は体重の増加はなく, その後 5 加まま では正常ラットと同じ早さで増加したが, 頭打ちに達し 7 か月目から減少した。 $\mathrm{Cr}$ は $5 / 6$ 腎摘により平均 0.4 $\mathrm{mg} / \mathrm{d} l$ から約 $1.2 \mathrm{mg} / \mathrm{d} l$ まで上昇し, 約 6 か月間は $1.2 \sim 1.5 \mathrm{mg}$ を保っていたがそれ以後急激に值が高く なっていった. CCr は 5/6 腎摘により正常值の約 $50 \%$ $(350 \mu \mathrm{l} / \mathrm{min} / 100 \mathrm{~g})$ まで低下し, それ以後経時的に悪く なっていった. 一方, 血中 $\mathrm{Ox}, \mathrm{VC}$ 值抢よび尿中の $\mathrm{Ox}$ 


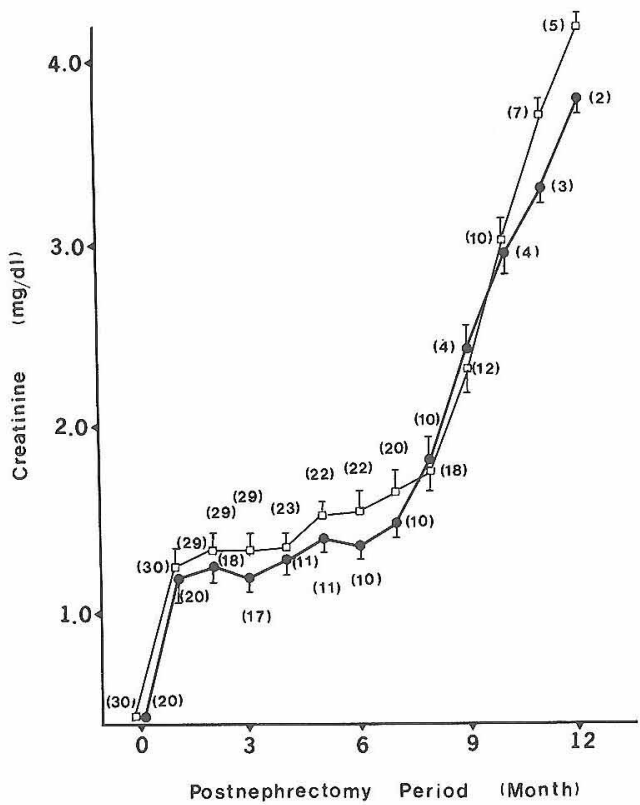

図 2 Plasma creatinine of $5 / 6$ nephrectomised rats treated and untreated with vitamin C. Parentheses indicate the number of rats.

表 1 Laboratory findings in the two groups of $5 / 6$ nephrectomised rats treated and untreated with vitamin C (mean \pm SEM)

\begin{tabular}{|c|c|c|c|c|}
\hline & \multirow{2}{*}{$\begin{array}{c}\text { Rats } \\
N\end{array}$} & \multicolumn{3}{|c|}{ Postnephrectomised month } \\
\hline & & 0 & 3 & 8 \\
\hline \multicolumn{5}{|c|}{ Plasma oxalate, $\mathrm{mcg} / \mathrm{ml}$} \\
\hline Healthy control & 6 & $0.4 \pm 0.2$ & & \\
\hline Treated rats & 6 & & $4.67 \pm 0.7^{*}$ & $5.82 \pm 0.9^{*}$ \\
\hline Untreated rats & 6 & & $2.60 \pm 0.4$ & $3.01 \pm 0.4$ \\
\hline \multicolumn{5}{|c|}{ Plasma vitamin $\mathrm{C}, \mathrm{mg} / \mathrm{d} l$} \\
\hline Healthy control & 6 & $0.2 \pm 0.03$ & & \\
\hline Treated rats & 6 & & $2.84 \pm 0.33^{*}$ & $6.76 \pm 0.25^{*}$ \\
\hline Untreated rats & 6 & & $0.41 \pm 0.08$ & $1.21 \pm 0.41$ \\
\hline \multicolumn{5}{|c|}{ Urinary oxalate, $\mathrm{mcg} / 24 \mathrm{~h} / 100 \mathrm{~g}$ bw } \\
\hline Healthy control & 6 & $245.5 \pm 10.7$ & & \\
\hline Treated rats & 6 & & $170.2 \pm 14.8$ & $65.7 \pm 8.7^{*}$ \\
\hline Untreated rats & 6 & & $151.4 \pm 17.2$ & $24.6 \pm 3.2$ \\
\hline
\end{tabular}

值は表 1 にまとめられている。

左残腎は上。下両極の焼灼部が脱落変形し，6 6 月以 上経過したラットでは肉眼的に腎囊胞の形成を認めるも のもある(図 4)。

組織学的には $\mathrm{VC}$ 投与の有無にかかわらず糸球体や間 質の硬化，細胞浸潤が経時的に進行していったが, $5 / 6$ 腎

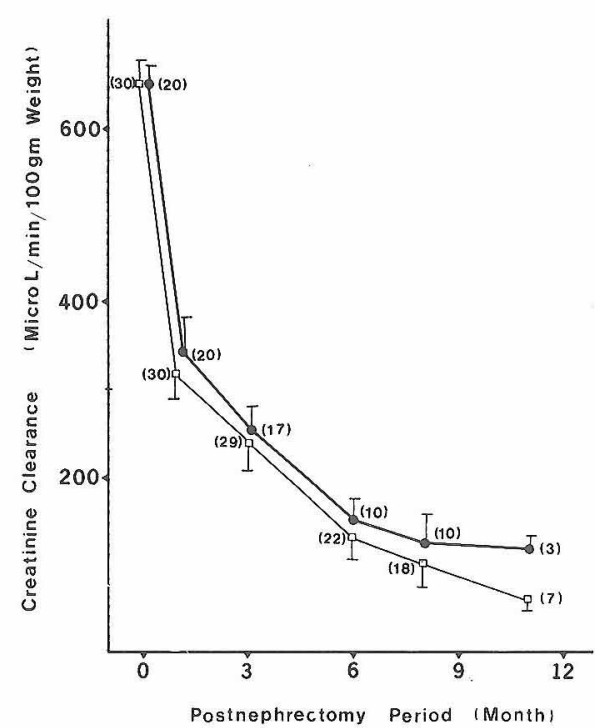

図 3 Creatinine clearance of $5 / 6$ nephrectomised rats treated and untreated with vitamin C. Parentheses indicate the number of rats.

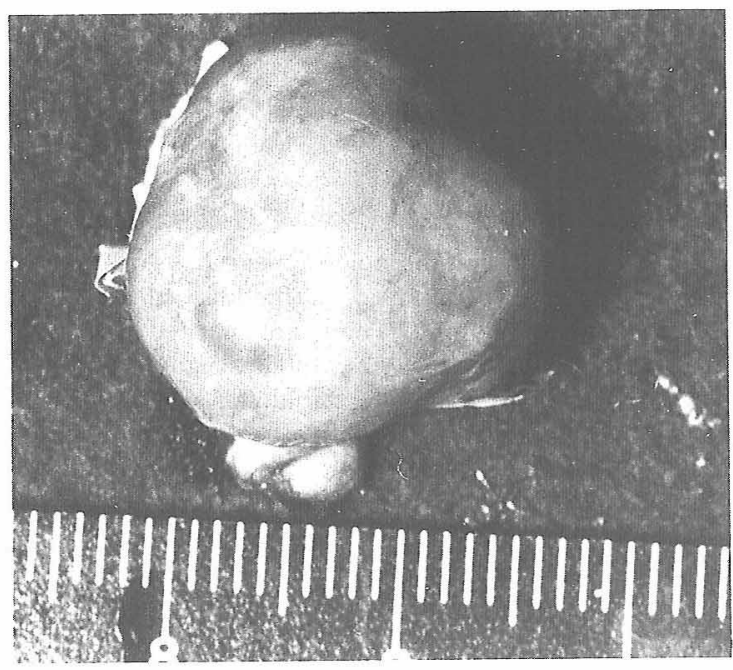

図 4 Gross appearance of the rat remnant kidney removed 11 months after $5 / 6$ nephrectomy. Note the large cyst on the surface of the kidney.

摘 11 か月後に犠牲死させた VC 投与ラットでは尿細管 に OxCa の沈着を認めた（図 $5 \mathrm{a} ， \mathrm{~b}$ )。しかし，尿細 管の拡張や囊胞形成は $\mathrm{OxCa}$ の㶩着が起こるより早期 に両群ラットに同じように認められた。

実験 II：A群の OxNa 投与ラットでは 5/6 䟝摘 12 日 目（OxNa 投与開始 5 日目）には尿細管に $\mathrm{OxCa}$ が沈着 

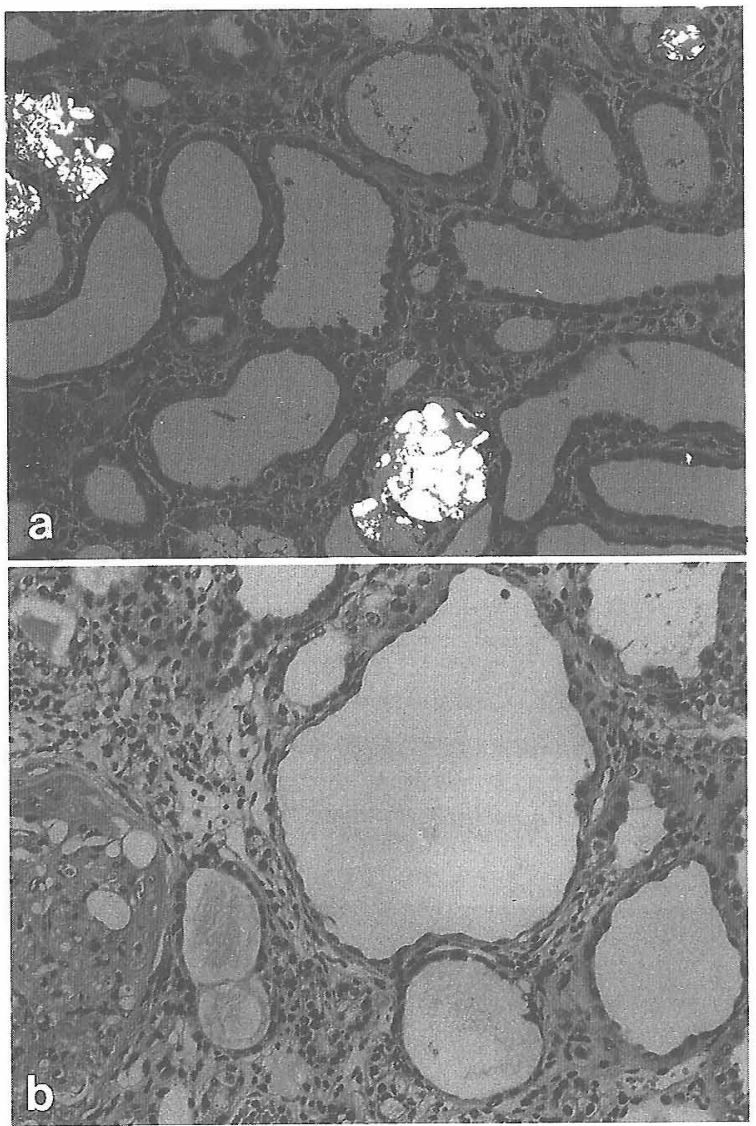

図 5 Light microscopic appearance of rat kidneys removed 11 months after $5 / 6$ nephrectomy. There are marked cystic dilatation of the tubules, glomerular sclerosis and interstitial cell infiltration. (a): Oxalate crystals are developed in renal tubules in vitamin $\mathrm{C}$-treated rat. $\mathrm{HE} \times 200$ in semipolarized light. (b) : Oxalate deposits are not seen in the kidney of rat without vitamin $\mathrm{C}$ supplementation. $\mathrm{HE} \times 200$

し,軽度ながら尿細管の拡張が起きていた。 $5 / 6$ 腎摘後 25 日目までは OxNa 投与の有無にかかわらず両群ラット の腎機能は同じであるのに，尿細管拡張は $\mathrm{OxNa}$ 投与 ラットで早期から起こり,しかも広範囲に認められた(表 2 , 図 6 a, b).

実験III：正常なラットに OxNa を与党ると約 2 週間 は腎機能低下はみられなかったが，早くも7日目には $\mathrm{OxCa}$ が尿細管内壁に沈着し，わずかながら尿細管の拡 張が起きていた。これらの組織学的な変化は経時的に強 くなり，それに伴い腎機能は 3 週目から低下しはじめた (表 3，図 7)。また，35日間 $\mathrm{OxNa}$ を与えたラットで

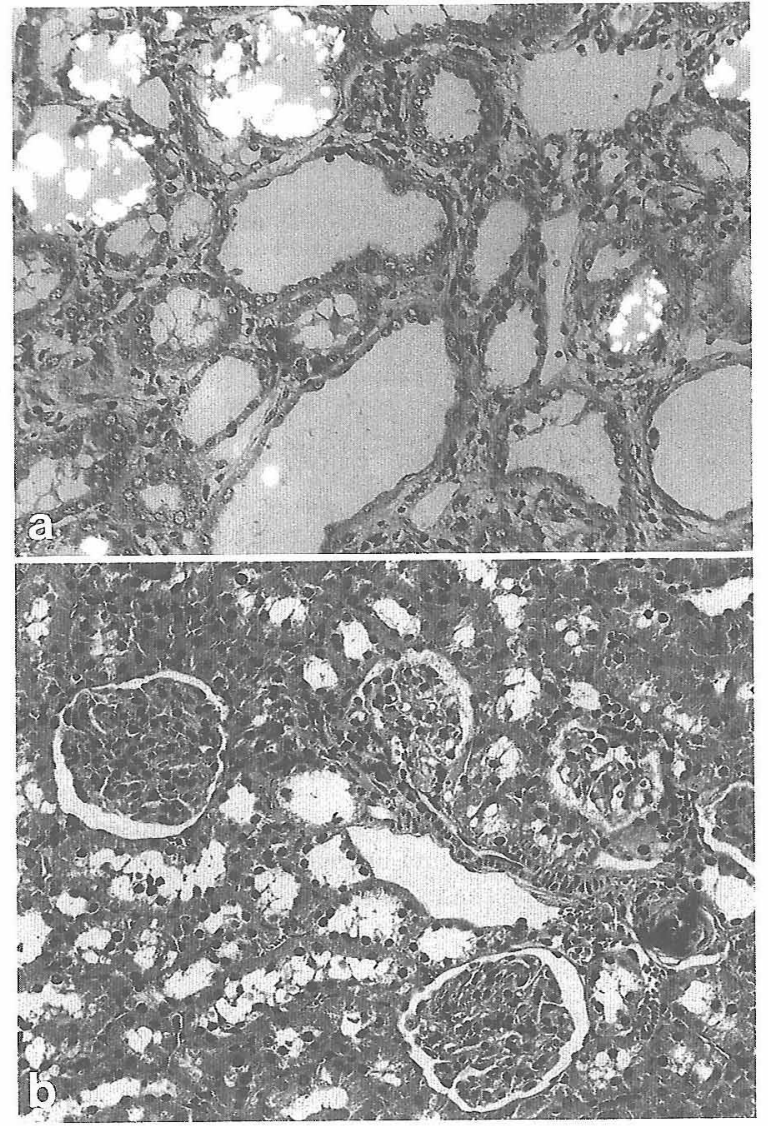

図 6 Histological appearance of remnant kidneys removed 25 days after $5 / 6$ nephrectomy in oxalate-treated (a) and untreated (b) rats. (a) : Severe degree of tubular dilation and oxalate deposits are seen. $\mathrm{HE} \times 200$ in semipolarized light. (b) : Tubular dilation is mild and oxalate is not seen. $\mathrm{HE} \times 200$

は心，肝，脾，甲状腺にごく微小な $\mathrm{CaOx}$ の沈着を認め たが、それに伴う二次的な組織変化はみられなかった(図 8).

\section{考案}

“多くの腎疾患は進行すると最終的に腎の線維化・菱 縮に陥る”と我々は病理学で教えられたし，また，排泄 機能がほとんど停止した末期腎不全患者の菱縮腎を検索 するほど興味がないものはないと 10 年前までは全く関 心が払われなかった。しかし，1977年に Dunnill ら゙が 剖検で得られた長期透析患者の病腎に後天性囊胞を認め て以来，これは各種の非囊胞性腎疾患が進行し到達した 最終的な姿であると考えられるようになっだ2。この後 天性腎囊胞に伴う腎の腫大，疼痛，出血あるいは悪性化 
表 2 Renal function and cyst formation of oxalate-treated and untreated $5 / 6$ nephrectomised rats

\begin{tabular}{|c|c|c|c|c|c|c|c|}
\hline $\begin{array}{l}\text { Days } \\
\text { after }\end{array}$ & $\begin{array}{l}\text { Rat } \\
N\end{array}$ & \multicolumn{2}{|c|}{$\begin{array}{l}\text { Plasma creatinine } \\
(\mathrm{mg} / \mathrm{d} l)\end{array}$} & \multicolumn{2}{|c|}{$\begin{array}{c}\text { Creatinine } \\
\text { clearance } \\
(\mathrm{mcg} / \mathrm{min} / 100 \mathrm{~g})\end{array}$} & \multicolumn{2}{|c|}{$\begin{array}{l}\text { Cyst } \\
\text { formation* }\end{array}$} \\
\hline \multicolumn{8}{|c|}{ Groups } \\
\hline & & A & B & A & B & A & B \\
\hline-1 & 1 & 0.38 & 0.37 & 630 & 633 & - & - \\
\hline 12 & 1 & 0.60 & 0.59 & 404 & 410 & \pm & - \\
\hline 19 & 1 & 0.61 & 0.59 & 384 & 387 & + & - \\
\hline 25 & 1 & 0.70 & 0.70 & 343 & 353 & H & \pm \\
\hline 31 & 1 & 1.11 & 0.81 & 202 & 321 & H & + \\
\hline 38 & 1 & 1.31 & 0.83 & 190 & 330 & m & + \\
\hline
\end{tabular}

$\mathrm{A}=$ Oxalate treated rats, $\mathrm{B}=$ Untreated rats

* Based on Pirani's method ${ }^{17)}$

表 3 Renal function and renal cyst formation of normal rats treated with sodium oxalate

\begin{tabular}{cccccc}
\hline $\begin{array}{l}\text { Rat } \\
\text { No }\end{array}$ & $\mathrm{N}$ & $\begin{array}{l}\text { Treatment } \\
\text { period } \\
\text { (days) }\end{array}$ & $\begin{array}{c}\text { Plasma } \\
\text { creatinine } \\
(\mathrm{mg} / \mathrm{d} l)\end{array}$ & $\begin{array}{c}\text { Creatinine } \\
\text { clearance } \\
(\mathrm{mcg} / \mathrm{min} / 100 \mathrm{~g})\end{array}$ & $\begin{array}{l}\text { Cyst } \\
\text { formation* }\end{array}$ \\
\hline 0 & 1 & 0 & 0.30 & 620 & - \\
1 & 1 & 7 & 0.31 & 625 & \pm \\
2 & 1 & 13 & 0.30 & 620 & + \\
3 & 1 & 21 & 0.42 & 521 & + \\
4 & 1 & 28 & 0.56 & 460 & + \\
5 & 1 & 35 & 0.58 & 410 & + \\
\hline
\end{tabular}

* Based on Pirani's method ${ }^{17}$

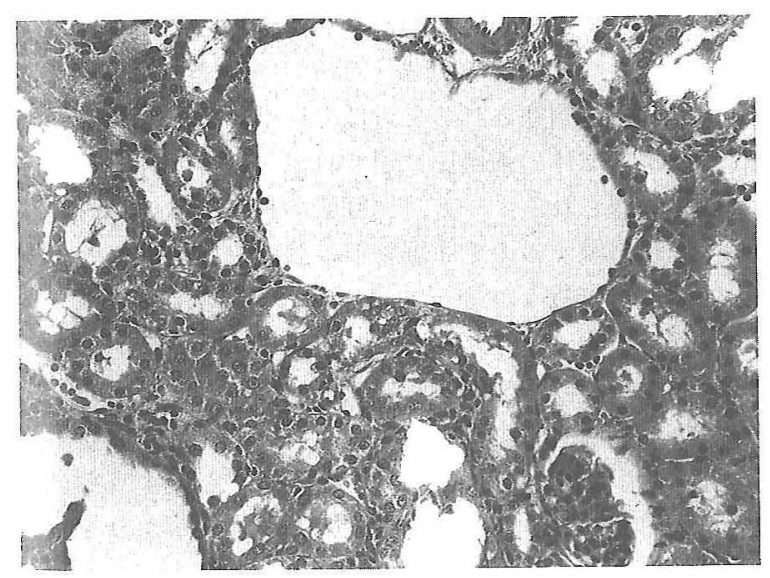

図 7 Kidney of normal rat treated with sodium oxalate for 35 days. Note tubular dilatation and oxalate crystal deposits in renal tubules. $\mathrm{HE} \times 200$ in semipolarized light.

などの臨床症状や合併症については興味を持たれ明らか になってきたが2,12)，しかし，その発生メカニズムについ
てはいまだ不明である。機能するネフロン数の減少に伴 う renotropic growth factor の放出，細胞毒性物質の蓄 積，㽷細管の狭窄・閉塞，尿細管の阻血，尿細管基底膜 の変性などによって後天性腎囊胞が発生するという仮説 が発表されてはいる ${ }^{127,12)}$.しかしながら，この発生メ力 ニズムの解明を実験的に試みた研究は少ない。長期透析 患者の剖検で得られた組織標本の検索から尿細管内の OxCa の沈着がしばしば囊胞と近接して認められること から，この両者の関連性を示唆する報告がなされてい $る^{3 \sim 5)}$ 。最近我々は 10 年以上透析された症例で血中 $\mathrm{Ox}$ 值と腎サイズとの間に強い相関性があることを報告7 し，高 Ox 血症加ら二次性に起こる尿酸管の $\mathrm{OxCa}$ 沈着 が後天性腎囊胞発生の一因になっているのではないかと 疑い，この点について腎不全および正常ラットで今回の 研究を行った。

まずラットを透析患者と同じレベルの㛑不全状態に して何らかの replacement therapy によって生かして観 察するのが望ましい方法であるが，技術的に不可能であ るので $5 / 6$ 腎摘にとどめて透析患者の腎機能よりはずっ と良好な状態で飼育観察せざるを得なかつた。したがっ 


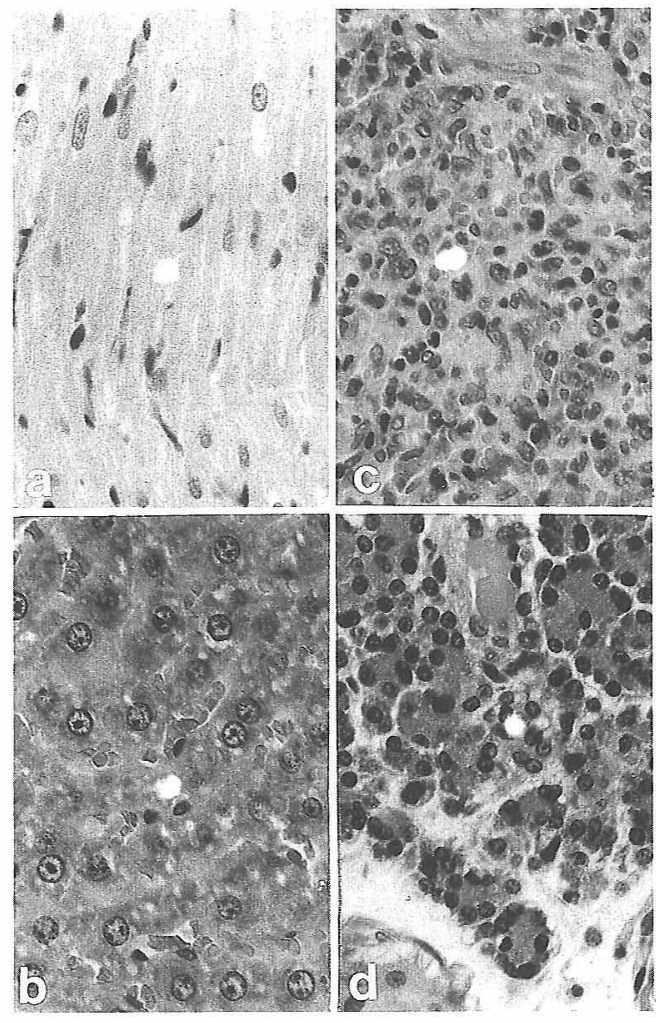

図 8 Histological appearance of heart (a), liver (b), spleen (c) and thyroid (d) of normal rat removed 35 days after injection of sodium oxalate. Minimum oxalate deposits are noted. $\mathrm{HE} \times 200$, semipolarized light.

て Oxの前駆物質であるVCを大量に与え $\mathrm{OxCa}$ の沈着 が早期に起こることを期待したが8)，1/6 残腎によって排 泄機能が長期に保たれているために5/6 腎摘 11 か月以 後にしか $\mathrm{OxCa}$ が沈着しなかった。この時点では VC投 与の有無にかかわらず $5 / 6$ 腎摘という急激な腎実質の減 少に起因すると考えられる renotropic growth factor の 放出 ${ }^{13 \sim 15)}$ ですでに多数の腎囊胞が形成されており， OxCa 沈着と腎囊胞形成との関連性はこの実験モデルで は解明されなかった。片側腎摘によって残腎が代償性に 肥大寸るという現象は古くから知られており ${ }^{16)}$ ，残腎か ら放出される物質によって支配されている15)。これは七 トの培養腎細胞に片側腎摘後の血清を加えると ${ }^{3} \mathrm{H}-$ thymidine の取り込みが増えて DNA の合成が増加する という in vitroの実験ではっきり証明されている ${ }^{15)}$ 。

実験IIおよびIIIでは大量の OxNa を経口的・経皮的に 直接 $5 / 6$ 腎摘および正常ラットに与えて早期に腎に $\mathrm{OxCa}$ を沈着させて鞟胞発生との関連を調べた。興味あ
ることには OxNa 投与の有無にかかわらず A・B 両群 ラットの腎機能は $5 / 6$ 腎摘後 4 週間目までは差異ないの に OxCa が沈着した OxNa 投与ラットの腎に囊胞が早 期にしかも強く形成された。これは負荷された OxNaが 唯一の排泄器官である腎で $\mathrm{OxCa}$ として尿細管内に沈 着し，その結果内腔が狭くなり内圧が高くなって囊胞が 形成されるというメカニズムを示唆している。さらに正 常ラットでも OxNa 負荷によって尿細管内に OxCa が 沈着し, 腎機能低下がない初期の段階で囊胞が発生した ので，少なくとも負荷された $\mathrm{OxNa}$ が OxCa に変わり 尿細管に沈着して囊胞形成の原因の一つになっているこ とを示している。

加齢による腎囊胞も知られているが, 体重測定用に 12 か月間飼育した正常ラットでは腎囊胞は認められなかっ たし，OxNaが与えられた正常ラットで7日目には早く も尿細管が拡張したことから，今回観察された腎囊胞は 加齢によるものではなく，OxNa 負荷によって血中 $\mathrm{Ox}$ 值が上昇し尿細管に OxCa が沈着したためと考えられ る。

血中 $\mathrm{Ox}$ の測定は操作が複雑で各種の測定法が試みら れ報告されて抢り，その正常值も $2 \sim 150 \mu \mathrm{mol} / l$ と大き なばらつきがある。今回採用した capillary gas chromatography 法は正常值が最も信頼性の高い in vivo のア イソトープ法とほとんど同じ程度であり，その信頼性と 再現性は広く認められている

組織学的に OxCa は多くは尿細管内壁に沈着し管腔 を狭小化しているが，この点が囊胞発生の重要な因子に なっているのではないだろうか？ 尿細管が $\mathrm{OxCa}$ に よって完全に閉塞されると近位の尿細管内圧が上昇し， この圧が系球体の濾過圧に達すれば糸球体の濾過は停止 すると予想される。一方，尿細管の狭窄では尿細管内圧 の上昇が持続するので尿細管が拡張し囊胞形成へと進む のではないだろうか？

今回の研究は $5 / 6$ 腎摘および正常ラットでの尿細管内 OxCa 沈着が後天性腎囊胞形成の一因であることを明確 に示している。腎実質が線維化し排泄機能が停止した末 期腎不全患者に多発する後天性腎囊胞がどのようなメ力 ニズムで発生するのか，その疑問を解く手がかりを与兄 るものと考えられる。

\section{結語}

OxNa を $5 / 6$ 腎摘および正常ラットに与えると尿細 管内に OxCa の結晶が沈着し，非投与ラットよりも早期 にしかも高度に尿細管の拡張や囊胞形成がみられる。こ れは OxCa の尿細管内沈着が後天性腎囊胞発生の一因 であることを明確に示している。 


\section{文献}

1) Dunnill MS, Millard PR, Oliver D : Acquired cystic disease of the kidneys: A hazard of long -term intermittent maintenance haemodialysis. J Clin Pathol $30: 868-877,1977$

2) Grantham JJ, Levine E: Acquired cystic disease : Replacing one kidney disease with another. Kidney Int $28: 99-105,1985$

3) Krempien B, Eberhard R : Acquired cystic transformation of the kidneys of haemodialysed patients. Virchows Arch 386 : 189-200, 1980

4) Mickisch O, Bommer J, Bachmann S, Waldherr R, Mann JFE, Ritz E : Multicystic transformation of kidneys in chronic renal failure. Nephron $38: 93$ $-99,1984$

5) Narasimhan N, Golper TA, Wolfaon M, Rahatzad M, Bennet WM : Clinical characteristics and diagnosis consideration in acquired renal cystic disease. Kidney Int $30: 748-752,1986$

6) Bommer J, Waldherr R, Ritz E : Kidney lesions in uraemic patients and beta-2-microglobulin derived amyloid. Lancet ii : 1437-1438, 1985

7) Ono K, Yasukohchi A, Kikawa K : Pathogenesis of acquired renal cystic (ARC) in hemodialysis patients. The role of oxalate crystal deposition in renal tubules. ASAIO $33: 245-249,1987$

8) Ono $\mathrm{K}:$ Secondary hyperoxalemia caused by vitamin $\mathrm{C}$ supplementation in regular hemodialysis patients. Clin Nephrol 26:239-243, 1986

9) Wolthers BG, Hayer $M$ : The determination of oxalic acid in plasma and urine by means of capillary gas chromatography. Clin Chim Acta $120: 87-102,1982$

10) Roe JH, Kuerther CA: The determination of ascorbic acid in the whole blood and urine through the 2,4-dinitrophenyl-hydrazine derative of dehydroascorbic acid. J Biol Chem $147: 399$ $-405,1953$

11) Ono K, Ono H, Ono $T$, Kikawa K, Oh $Y$ : Effect of vitamin $\mathrm{C}$ supplementation of renal oxalate deposits in five-sixths nephrectomised rats. $\mathrm{Ne}$ phron $51: 536-539,1989$

12) Ishikawa $I:$ Uremic acquired cystic disease of kidney. Urology 26 : 101-108, 1985

13) Dicker SE, Morris CA : Presence of renotropic factors in plasma of unilaterally nephrectomised rats. J Physiol 299 : 13-27, 1980

14) Preuss HG, Golden $H:$ A renotropic system in rats. J Clin Invest $57: 94-101,1976$

15) Yamada J, Kanetake H, Saito $Y$, Kondo A, Yamamoto N : Renotropic growth factor in cancer patient sera after removal of cancer-bearing kidney. Kidney Int $23:$ 632-634, 1983

16) Saphir $O$ : The state of the glomerulus in experimental hypertrophy of the kidney of rabbits. Am J Pathol 3 : 329-342, 1927

17) Pirani CL, Pollack VE, Schwartz FD: The reproducibility of semiquantitative analysis of renal histology. Nephron $1: 230-236,1964$

18) Dorhout Mees EJ, Boer MP : Plasma oxalate in chronic renal failure and normal subjects. Methological problems. Nephron $48: 256-257,1988$ 